\title{
Effect of Feeding Multi-Strain Probiotic on Feed Intake and Milk Production Performance in Murrah Buffaloes
}

\author{
Y. Yaswanth Naidu ${ }^{1 *}$, K. Ananda Rao ${ }^{2}$, Ch. Venkata Seshaiah ${ }^{3}$, \\ D. Srinivas Kumar ${ }^{4}$ and M. Sri Lekha ${ }^{5}$
}

${ }^{1}$ Department of Livestock Production, NTR College of Veterinary Science, Sri Venkateswara Veterinary University, Gannavaram, Andhra Pradesh, India

${ }^{2}$ Buffalo Research Station, Venkataramannagudem, West Godavari, Andhra Pradesh, India

${ }^{3}$ Department of Livestock Farm Complex,

${ }^{4}$ Department of Animal Nutrition,

${ }^{5}$ Department of Livestock Production Management, NTR College of Veterinary Science, Sri

Venkateswara Veterinary University, Gannavaram, Andhra Pradesh, India

*Corresponding author

\section{A B S T R A C T}

Keywords

Murrah buffaloes, milk production performance, multistrain probiotic, dry matter intake, milk yield, body condition score

Article Info

Accepted:

12 April 2021

Available Online:

10 May 2021
Twelve Murrah buffaloes(in their early lactation) were divided into two groups of six buffaloes each on the basis of average daily milk yield. Group I was set as control and Group-II was supplemented with multi-strain probiotic @ $20 \mathrm{gm} / \mathrm{animal} /$ day for a period of 90 days. The feed intake, body condition score (BCS), feed conversion ratio (FCR), milk yield and 6\% fat corrected milk yield were recorded. Significant difference in mean DMI $(\mathrm{kg} / \mathrm{d})$ was not observed between the treatment and control groups. The average daily milk yield was significantly $(\mathrm{P}<0.05)$ higher in treatment group compared to control group of buffaloes. The feed conversion ratio $(\mathrm{FCR})$ was significantly $(\mathrm{P}<0.05)$ low in treatment group compared to control group of buffaloes. Supplementation of multi-strain probiotic did not have any influence on body condition score in Murrah buffaloes. The present research concludes that multi-strain probiotic supplementation @20gms/animal/day significantly lowered the FCR and significantly increased the milk yield in Murrah buffaloes.

\section{Introduction}

Livestock sector plays an important role in Indian economy and is an essential part of Indian agriculture. India is regarded as a home of world's best buffalo germplasm. Among the Indian buffalo breeds, Murrah breed is unique and popular for its milk production. Murrah buffaloes are found throughout the country due to their higher milk production 
potential coupled with adaptation to wide environmental conditions and feed conversion efficiency. Hence, it has been appropriately named as the black gold of India. Buffalo milk plays an important role in providing nutritive food to families both in rural and urban areas. Composition of milk is economically important to milk producers, important to dairy industries for producing better quality products and nutritionally important to milk consumers for their health. Nowadays along with fat percentage, other milk components such as solid not fat (SNF), total solids (TS), protein, lactose and ash are also measured (Malek dos Reis et al., 2013). Milk fat represents chief constituent of buffalo milk followed by lactose and protein.

Modern dairy farms are targeting high milk production utilizing feed composed of high concentrates to meet the metabolic demand of the higher milk production. Such feeding system is associated with metabolic dysfunctions especially during poor feeding condition and composition. One of the novel approach to counter the effects of metabolic disorders and to improve the milk production in dairy animals is the supplementation of probiotics.

Probiotics are live micro-organisms which when administered in adequate amounts confer a health benefit on the host (WHO). Most of commercial products use multi-strain probiotics, although the benefits of incorporating more strain and/or species in one product has not been clearly determined. The microorganisms, that are frequently used as probiotics in animal feeds includes, lactic acid bacteria (such as Lactobacillus spp., Streptococci spp., Bifidobacterial spp.) and anaerobic fungi (yeast) (i.e. Saccharomyces cerevisiae, Saccharomyces boulardii and Aspergillus oryzae) that are normally, found in the gut of the animal (Jouany and Morgavi, 2007).In dairy animals, probiotics are commonly used to improve ruminal and intestinal microflora populations, consequentially enhance the performance and health of animal, and boosts synthesis of protein and vitamins, as well as milk production and compositions. Several researchers reported that milk yield, milk fat yield, milk protein yield, casein yield, lactose percentage, total solid and solid-not-fat were significantly improved with probiotic feeding (Iwanska et al., 2000; Meeske et al., 2002 ; Hossain, et al., 2014). Most of the literatures enlists that, modification of rumen microbial populations, enhancing feed digestibility and nutrient absorption, rumen $\mathrm{pH}$ regulation, colonization of gastro-intestinal tracts and competitive exclusion of pathogenic agents, production of antimicrobial substances and altering gene expression of pathogenic microorganisms were among common modes of action of probiotics in improving the production performance of dairy animals. Since there is paucity of information on the effect of feeding multi-strain probiotics on milk production performance in Murrah buffaloes, the present research is proposed with the following objectives to find effect of multi-strain probiotic supplementation on feed intake, body condition score, milk production, milk constituents and cost on milk production in Murrah buffaloes.

\section{Materials and Methods}

Twelve Murrah buffaloes in their early lactation were selected from Buffalo Research Station, Venkataramannagudem and divided into two groups of six buffaloes each on the basis on average daily milk yield in a completely randomized design (CRD). The average daily milk yield in each of the groups was similar before the start of the experiment. All the buffaloes were housed individually in a well-ventilated shed with a provision for individual feeding and watering facilities. The shed was provided with concrete flooring and 
asbestos roof with good ventilation facilities. All the buffaloes were fed with chopped green fodder (Hybrid Napier), dry fodder (paddy straw) and concentrate as the basal diet individually as per their nutrient requirements (ICAR 2013). The buffaloes were divided into two groups i.e. Group I is control and GroupII was supplemented with multi-strain probiotic containing 6 bacterial strains (Lactobacillus acidophilus, Lactobacillus bulgaricus, Lactobacillus casei, Lactobacillus returi, Lactobacillus lactis, Streptococcus faecium) and 2 yeast strains (Aspergillus oryzae, Saccharomyces cervisiae) $\left(2 \times 10^{9} \mathrm{cfu} / \mathrm{gm}\right) @ 20 \mathrm{gm} / \mathrm{animal} /$ day for a period of 90 days.

All the experimental buffaloes were identified using ear tags. All the animals were vaccinated against $\mathrm{HS}$ and FMD and were dewormed one week prior to the start of the experiment. All the animals were allowed to have adaptation period for 15 days before the actual trail, during which they were fed with basal diet. After the adaptation period animals were fed with their respective treatment diets for 90 days. The diet of the experimental animals included chopped Hybrid Napier as roughage source and concentrate mixture. The feeding and watering of experimental animals was done individually and the amount of concentrate mixture and fodder was offered as per their nutrient requirement (ICAR 2013). The multi-strain probiotic Lactose Plus ${ }^{\circledR}$ was procured from International Health Care Limited, Vijayawada, Andhra Pradesh. The probiotic was mixed with concentrate mixture and offered as per the dose rate. Concentrate mixture was offered daily before milking the animals and green fodder at 10:00 $\mathrm{h}$ and 15:00 h. Clean drinking water was made available to animals round the clock. Daily feed offerings and refusals were recorded prior to the morning feeding to obtain feed intake of each animal. The leftover of the concentrate mixture, if any was weighed one hour after it was offered. Feed intake $(\mathrm{kg})$ was obtained at every 24 hours by subtracting the quantity of feed left from the quantity of feed offered. Milking was done twice daily (AM and PM) and milk yield records were maintained throughout the experimental period (90 days after start of experimental period). Daily milk yield was obtained by adding AM and PM yields. Feed conversion ratio was calculated by dividing the total DMI $(\mathrm{kg})$ by the milk yield $(\mathrm{kg})$ of the experimental animals. Body condition score (BCS) was determined by using BCS scale developed by Alapati et al., (2010). The Body condition score will be studied at monthly intervals. The properly classified and tabulated data collected during the experimental period were subjected to statistical analysis by adopting appropriate methods of analysis of variance as described by Snedecor and Cochran (1994). The data obtained was analyzed according to statistic computer program SPSS version (15.01) (SPSS, 2006).

\section{Results and Discussion}

\section{Dry matter intake}

The effect of multi-strain probiotic supplementation on mean DM intake (DMI) in Murrah buffaloes is represented in the Table 1. The results of the present study revealed that there was no significant difference in DMI (kg/d and \% body weight) between the treatment and control groups. Similar results of non-significant difference in DM intake with probiotic supplementation was reported by Gujjar et al., (2006) in lactating buffaloes. The DM intake was also not influenced with supplementation of Saccharomyces cerevisiae or Aspergillus oryzae (Bach et al., 2007) in Holstein cows. Kumar (et al., 2016c) observed no significant difference in DMI (\% body weight) with probiotic supplementation on lactating Barbari goats corroborated with present results. The present results were also 
consistent with the findings of Arambel and Kent (1990); Wholt et al., (1991); Soder and Holden (1999); Schingoethe et al., (2004) who reported no significant difference in DM intake in lactating cows supplemented with probiotic. Earlier reports revealed that probiotics are metabolically active in the rumen, at least for a short time (Kung et al., 1997), thereby modifying ruminal fermentation and stimulating microbial growth (Erasmus et al., 2005). Such changes are often associated with increased dietary fiber digestibility (Guedes et al., 2008), which could increase rate of passage and therefore improve DMI. In the current study, multistrain probiotic supplementation was improved DMI in buffaloes compared to the control, but the difference was not significant. Contrary to the present findings, Alshaikh et al., (2002) and Kumar et al., (2011b) reported a decrease and increase in DMI in cows and Graded Murrah buffaloes, respectively supplemented with yeast culture.

\section{Effect on daily milk yield (kg) and $6 \%$ fat} corrected milk yield

Effect of probiotic supplementation on average daily milk yield $(\mathrm{kg})$ and $6 \%$ fat corrected milk yield in Murrah buffaloes is represented in the Table 2 . From $2^{\text {nd }}$ week onwards, the average daily milk yield started to increase in probiotic supplemented buffaloes compared to the control buffaloes and the difference was statistically significant $(\mathrm{P}<0.05)$ from $8^{\text {th }}$ week onwards till the end of the experiment. From $2^{\text {nd }}$ week onwards, the $6 \%$ fat corrected milk yield started to increase in probiotic supplemented buffaloes compared to the control buffaloes and the difference was statistically significant $(\mathrm{P}<0.05)$ from $9^{\text {th }}$ week onwards till the end of the experiment. The results obtained in the present study is consistent with the findings of El-Bordeny et al., (2019) who reported increased milk production in Egyptian buffaloes supplemented with yeast-based probiotics. Similar results of increased milk yield and $4 \%$ fat corrected milk yield $(\mathrm{P}<0.05)$ was reported in probiotic supplemented buffaloes compared to the control (Azzaz et al., 2015). A significant $(\mathrm{P}>0.05)$ increase in $6 \%$ fat corrected milk (FCM) yield was also observed by Kumar et al., (2011b) in probiotic supplemented buffaloes over to the control group. Increase in $4 \%$ fat corrected milk in probiotic supplemented cows reported by several earlier studies (Sretenovic et al., 2008; Alshaikh et al., 2002; Moallem et al., 2009) corroborated with present research. In a similar study, milk yield was increased from third week onwards in cows supplemented with multi-strain probiotic (Vibhute et al., 2011) is consistent with present findings. Parallel to the present findings, Shreedhar et al., (2016) reported that multi-strain probiotic supplementation increased milk production in crossbred cows. In the present study, multistrain probiotic supplementation increased $15.53 \%$ milk yield in Murrah buffaloes compared to the control. Similar results of 11.5 and $12.7 \%$ higher daily milk yield was reported with probiotic feeding in cows (Diler at al.,2014). Parallel to the present findings Yasuda et al., (2007) reported 3-16\% increase of milk production in Holstein Friesian cows with probiotics supplementation.

The increased milk production with multistrain probiotic supplementation in buffaloes in the present study might be due to the altered rumen fermentation patterns in favour of propionate, (Aikman et al., 2011) and stabilization of ruminal $\mathrm{pH}$ which improved propionic acid production resulted increased milk production (Beauchemin et al., 2003). Further, the yeast in the multi-strain probiotic supplementation may increase the cellulolytic bacteria and fibre digestion in the feed (Denev et al., 2007). 
Table.1 Effect of probiotic supplementation on dry matter intake in Murrah buffaloes

\begin{tabular}{|c|c|c|}
\hline Week & \multicolumn{2}{|c|}{ Dry matter intake (kg) } \\
\hline & $\mathbf{C}$ & $\mathbf{T}$ \\
\hline $\mathbf{1}$ & $17.58 \pm 0.12$ & $17.59 \pm 0.33$ \\
\hline $\mathbf{1 2}$ & $19.45 \pm 0.17$ & $22.40 \pm 0.25$ \\
\hline Overall mean & $18.59 \pm 0.21$ & $19.52 \pm 0.34$ \\
\hline
\end{tabular}

Table.2 Effect of probiotic supplementation on daily milk yield and $6 \%$ fat corrected milk in Murrah buffaloes

\begin{tabular}{|c|c|c|c|}
\hline \multirow{3}{*}{ Daily milk yield } & Week & C & T \\
\cline { 2 - 4 } & 1 & $7.58 \pm 0.5$ & $7.61 \pm 0.31$ \\
\cline { 2 - 4 } & $12^{*}$ & $9.14 \pm 0.1^{\mathrm{a}}$ & $11.78 \pm 0.36^{\mathrm{b}}$ \\
\hline \multirow{3}{*}{$\begin{array}{c}\text { 6\% fat corrected } \\
\text { milk }\end{array}$} & Overall mean $^{\mathrm{a}}$ & $8.24 \pm 0.34^{\mathrm{a}}$ & $9.52 \pm 0.14^{\mathrm{b}}$ \\
\cline { 2 - 4 } & 1 & $8.51 \pm 0.16$ & $8.52 \pm 0.39$ \\
\cline { 2 - 4 } & $1^{*}$ & $8.94 \pm 0.14^{\mathrm{a}}$ & $10.47 \pm 0.23^{\mathrm{b}}$ \\
\hline
\end{tabular}

Means with different superscripts in a row differ significantly $(* \mathrm{P}<0.05)$.

Table.3 Effect of probiotic supplementation on feed conversion ratio in Murrah buffaloes

\begin{tabular}{|c|c|c|}
\hline Week & \multicolumn{2}{|c|}{ Feed conversion ratio } \\
\hline & $\mathbf{C}$ & $\mathbf{T}$ \\
\hline $\mathbf{1}$ & $2.31 \pm 0.32$ & $2.31 \pm 0.31$ \\
\hline $\mathbf{1 2}^{*}$ & $2.12 \pm 0.45^{\mathrm{a}}$ & $1.89 \pm 0.21^{\mathrm{b}}$ \\
\hline Overall mean & $2.25 \pm 0.33^{\mathrm{a}}$ & $1.73 \pm 0.13^{\mathrm{b}}$ \\
\hline \multicolumn{2}{|c|}{ Means with different superscripts in a row differ significantly $(* \mathrm{P}<0.05)$} \\
\hline
\end{tabular}

Table.4 Effect of probiotic supplementation on body condition score in Murrah buffaloes

\begin{tabular}{|c|c|c|}
\hline Days & \multicolumn{2}{|c|}{ Body condition score } \\
\hline & C & T \\
\hline 0th Day & $3.16 \pm 0.15$ & $3.2 \pm 0.13$ \\
\hline 90th Day & $3.47 \pm 0.26$ & $3.51 \pm 0.15$ \\
\hline Overall mean & $3.29 \pm 0.10$ & $3.36 \pm 0.11$ \\
\hline
\end{tabular}

Yeast supplements containing Saccharomyces cerevisiae, are known to be rich sources of enzymes, vitamins, other nutrients and important co-factors, have been reported to produce a variety of beneficial production responses (Rai et al., 2013). Probiotics may also improve the immune mechanism against the gastrointestinal pathogens and hence more productivity (Walker, 2008). However, Raeth- knight et al., (2007) observed no significant effect of direct fed microbials in the milk yield of Holstein dairy cows.

\section{Feed Conversion Ratio (FCR)}

Effect of multi-strain probiotic supplementation on feed conversion ratio in Murrah buffaloes is represented in the Table 3. 
From $2^{\text {nd }}$ week onwards, the feed conversion ratio (FCR) was decreased in probiotic supplemented buffaloes compared to the control buffaloes and the difference was statistically significant $(\mathrm{P}<0.05)$ from $8^{\text {th }}$ week onwards. The results of the present study are consistent with the findings of Zhang et al., (2013) who reported decreased FCR in probiotic supplemented buffaloes compared to the control. The increased feed efficiency reported by Hansen et al., (2017) in probiotic supplemented buffaloes also corroborated with present findings. Similar results of increased feed efficiency with probiotic supplementation also reported by several authors (Hagg et al., 2010; Moallem et al., 2009; Schingoethe et al., 2004) in cows. The multi-strain probiotic supplementation might have increased various digestive processes, especially cellulolysis and the synthesis of microbial proteins. The cells of Saccharomyces cerevisiae provide growth factors for rumen microbes, including organic acids and oligosaccharides, B vitamins, and amino acids, which stimulate microbial growth in the rumen, thereby indirectly stabilizing ruminal $\mathrm{pH}$ (McDonald et al., 2011). This might be responsible for better FCR in probiotic supplemented buffaloes

\section{Body condition score}

Effect of multi-strain probiotic supplementation on mean body condition score in Murrah buffaloes is represented in the Table 4. The results of the present study revealed that the BCS was not significantly different between the control and experimental buffaloes throughout the experiment. Similar findings were observed by Dann et al., (2000), Nocek and Kautz (2006) and Bruno et al., (2009) who reported no significant difference in mean body condition score when cows supplemented with probiotics. Previous reported data on Holstein Friesian dairy cows (Berry et al., 2006) revealed that the average change in body weight per unit change in BCS (scale of 1 to 10) was $31 \mathrm{~kg}$. Enevoldsen and Kirstensen (1997) reported that a change of 1 unit in BCS (scale 1 to 5) was associated with a change of 32 to $47 \mathrm{~kg} \mathrm{LWT}$, while Grainger, Wilhems and McGowan (1982) reported a change of $42 \mathrm{~kg}$ LWT per unit change in BCS (scale 1 to 8 ). In the present study, the BCS was high in probiotic supplemented buffaloes but the difference was not significant. From the above findings it was evident that due to less difference in bodyweight changes during lactation between the treatment and control groups, the BCS difference may be not significant between the groups.

Multi-strain probiotic may be supplemented to the buffaloes @ 20gms/animal/day for economic milk production. Milk quantity and quality in terms of its constituents may be improved particularly under roughage-based buffalo productions system.

\section{References}

Aikman, P. C., Henning, P. H., Humphries, D. J., \& Horn, C. H. 2011 Rumen $\mathrm{pH}$ and fermentation characteristics in dairy cows supplemented with Megasphaera elsdenii NCIMB 41125 in early lactation. Journal of dairy science, 94(6), 2840-2849.

Alapati, A., Kapa, S. R., Jeepalyam, S., Rangappa, S. M. P., \& Yemireddy, K. R. 2010 Development of the body condition score system in Murrah buffaloes: validation through ultrasonic assessment of body fat reserves. Journal of veterinary science, 11(1), 1-8.

Alshaikh, M. A., Alsiadi, M. Y., Zahran, S. M., Mogawer, H. H., \& Aalshowime, T. A. 2002 Effect of feeding yeast culture from different sources on the performance of lactating Holstein cows in Saudi Arabia. Asian-australasian journal of animal sciences, 15(3), 352356. 
Arambel, M. J., \& Kent, B. A.1990 Effect of yeast culture on nutrient digestibility and milk yield response in early-to midlactation dairy cows. Journal of Dairy Science, 73(6), 1560-1563.

Azzaz, H. H., Ebeid, H. M., Morsy, T. A., \& Kholif, S. M. 2015 Impact of feeding yeast culture or yeast culture and propionibacteria 169 on the productive performance of lactating buffaloes. Int. J. Dairy Sci, 10, 107-116.

Bach, A., Iglesias, C., \& Devant, M. 2007 Daily rumen $\mathrm{pH}$ pattern of loose-housed dairy cattle as affected by feeding pattern and live yeast supplementation. Animal Feed Science and Technology, 136(1-2), 146-153.

Beauchemin, K. A., Yang, W. Z., Morgavi, D. P., Ghorbani, G. R., Kautz, W., \& Leedle, J. A. Z. 2003 Effects of bacterial direct-fed microbials and yeast on site and extent of digestion, blood chemistry, and subclinical ruminal acidosis in feedlot cattle. Journal of Animal Science, 81(6), 1628-1640.

Berry, D., Macdonald, K. A., Penno, J. W., \& Roche, J. R. 2006 Association between body condition score and live weight in pasture-based Holstein-Friesian dairy cows.

Bruno, R. G., Rutigliano, H. M., Cerri, R. L., Robinson, P. H., \& Santos, J. E. 2009 Effect of feeding Saccharomyces cerevisiae on performance of dairy cows during summer heat stress. Animal Feed Science and Technology, 150(3-4), 175186.

Dann, H. M., Drackley, J. K., McCoy, G. C., Hutjens, M. F., \& Garrett, J. E. 2000 Effects of yeast culture (Saccharomyces cerevisiae) on prepartum intake and postpartum intake and milk production of Jersey cows. Journal of Dairy Science, 83(1), 123-127.

Denev $\mathrm{S}$ A, $\mathrm{T}$ Z Peeva, $\mathrm{P}$ Radulova, $\mathrm{P}$ Stancheva, G Staykova, G Beev, $P$
Todorova and S Tchobanova 2007 Yeast cultures in ruminant nutrition. Bulgarian Journal of Agricultural Science 13: 357-374.

Diler, A., Kocyigit, R., Yanar, M., \& Aydin, R. 2013 Effect of feeding direct-fed microbials plus exogenous feed enzymes on milk yield and milk composition of Holstein Friesian cows. Veterinarija Ir Zootechnika, 65(87).

Dos Reis, C. B. M., Barreiro, J. R., Mestieri, L., de Felício Porcionato, M. A., \& dos Santos, M. V. 2013 Effect of somatic cell count and mastitis pathogens on milk composition in Gyr cows. $B M C$ veterinary research, 9(1), 67.

El-Bordeny, N. E., Abdou, A., Abo-Eid, H., Abdo, M. M., \& Abdel-Gawad, R. M. A. 2019 Effect of yeast-based probiotics supplementation on the productive and reproductive performance of lactating buffaloes. Egyptian Journal of Nutrition and Feeds, 22(1), 33-44.

Enevoldsen, C., \& Kristensen, T. 1997 Estimation of body weight from body size measurements and body condition scores in dairy cows. Journal of dairy science, 80(9), 1988-1995.

Erasmus, L. J., Robinson, P. H., Ahmadi, A., Hinders, R., \& Garrett, J. E. 2005 Influence of prepartum and postpartum supplementation of a yeast culture and monensin, or both, on ruminal fermentation and performance of multiparous dairy cows. Animal Feed Science and Technology, 122(3-4), 219239.

Guedes, C. M., Goncalves, D., Rodrigues, M. A. M., \& Dias-da-Silva, A. 2008 Effects of a Saccharomyces cerevisiae yeast on ruminal fermentation and fibre degradation of maize silages in cows. Animal Feed Science and Technology, 145(1-4), 27-40.

Gujjar, S. R., Ahmad, M., \& Javid, R. S. 2006 Effect of Biovet and probiotic (BM- 
technology) on milk production in lactating buffaloes. Pakistan Veterinary Journal, 26(4), 201.

Hagg, F. M., Erasmus, L. J., Henning, P. H., \& Coertze, R. J. 2010 The effect of a direct fed microbial (Megasphaera elsdenii) on the productivity and health of Holstein cows. South African Journal of Animal Science, 40(2).

Hansen, H. H., El-Bordeny, N. E., \& Ebeid, H. M. 2017 Response of primiparous and multiparous buffaloes to yeast culture supplementation during early and midlactation. Animal Nutrition, 3(4), 411418.

Hossain, F. M. A., Islam, M. M., Ara, A., \& Iliyas, N. 2014 Supplementing probiotics (Saccharomyces cerevisiae) in multiparous crossbred cows ration provoke milk yield and composition. Online J. Anim. Feed Res, 4(2), 18-24.

ICAR 2013 Nutrient Requirements of Cattle and Buffalo. Indian Council of Agricultural Research New Delhi.

Iwańska, S., Strusińska, D., \& Opałka, A. 2000 Effect of biologically active compounds on milk yield and composition. Roczniki Naukowe Zootechniki, (Supl. z. 6), 46-50. Meeske, R., Van der Merwe, G. D., Greyling, J. F., \& Cruywagen, C. W. 2002. The effect of the addition of a lactic acid bacterial inoculant to maize at ensiling on silage composition, silage intake, milk production and milk composition.

Jouany, J. P., \& Morgavi, D. P. 2007 Use of'natural'products as alternatives to antibiotic feed additives in ruminant production. Animal: an international journal of animal bioscience, 1(10), 1443.

Kumar D S, Prasad J R and Rao E R 2011a Effect of dietary inclusion of yeast culture (Saccharomyces cerevisiae) on growth performance of graded Murrah buffalo bull calves. Buffalo Bulletin 30(1):63-66.

Kumar M, Dutta T K, Chaturvedi I 2016c Effect of probiotics supplementation on live weight in lactating Barbari goats. Journal of Biological Sciences and Medicine 2(3):24-30.

Kumar S D, Prasad J R and Rao E R 2011b Effect of supplementation of yeast culture in the diet on milk yield and composition in graded Murrah buffaloes. Buffalo Bulletin 30: 100.

Kung Jr, L., Kreck, E. M., Tung, R. S., Hession, A. O., Sheperd, A. C., Cohen, M. A. \& Leedle, J. A. Z. 1997 Effects of a live yeast culture and enzymes on in vitro ruminal fermentation and milk production of dairy cows. Journal of dairy Science, 80(9), 2045-2051.

McDonald, P., Edwards, R. A., Greenhalgh, J. F. D., Morgan, C. A., Sinclair, L. A., \& Wilkinson, R. G. 2011 Food additives. Animal Nutrition. Seventh ed. Pearson Education Ltd., Harlow, 594-607.

Moallem, U., Lehrer, H., Livshitz, L., Zachut, M., \& Yakoby, S. 2009 The effects of live yeast supplementation to dairy cows during the hot season on production, feed efficiency, and digestibility. Journal of Dairy Science, 92(1), 343351.

Nocek, J. E., \& Kautz, W. P. 2006 Direct-fed microbial supplementation on ruminal digestion, health, and performance of pre-and postpartum dairy cattle. Journal of Dairy Science, 89(1), 260-266.

Raeth-Knight, M. L., Linn, J. G., \& Jung, H. G. 2007 Effect of direct-fed microbials on performance, diet digestibility, and rumen characteristics of Holstein dairy cows. Journal of Dairy Science, 90(4), 1802-1809.

Schingoethe, D. J., Linke, K. N., Kalscheur, K. F., Hippen, A. R., Rennich, D. R., \& Yoon, I. 2004 Feed efficiency of mid- 
lactation dairy cows fed yeast culture during summer. Journal of Dairy Science, 87(12), 4178-4181.

Shreedhar, J. N., Patil, M., \& Kumar, P. 2016 Effect of probiotics supplementation on milk yield and its composition in lactating Holstein Fresien and Deoni cross bred cows. Journal of Medical and Bioengineering Vol, 5(1).

Snedecor, G. W., \& Cochran, W. G. 1994 Statistical methods. Viii edn.

Soder, K. J., \& Holden, L. A. 1999 Dry matter intake and milk yield and composition of cows fed yeast prepartum and postpartum. Journal of dairy science, 82(3), 605-610.

SPSS version (15.01) 2006, Chicago. IL: SPSS Inc. 2006.

Sretenović, L., Petrović, M. P., Aleksić, S., Pantelić, V., Katić, V., Bogdanović, V., \& Beskorovajni, R. 2008 Influence of yeast, probiotics and enzymes in rations on dairy cows performances during transition. Biotechnology in Animal Husbandry, 24(5-6), 33-43.

Vibhute, V. M., Shelke, R. R., Chavan, S. D., \& Nage, S. P. 2011 Effect of probiotics supplementation on the performance of lactating crossbred cows. Veterinary World, 4(12), 557.
V Rai, B Yadav and G P Lakhani 2013 Application of probiotic and prebiotic in animal production: A review Environment \& Ecology, vol. 31, no. 2B, pp. 873-876.

Walker, W. A. 2008 Mechanisms of action of probiotics. Clinical Infectious Diseases, 46 (Supplement_2), S87-S91.

Wohlt, J. E., Finkelstein, A. D., \& Chung, C. H. 1991 Yeast culture to improve intake, nutrient digestibility, and performance by dairy cattle during early lactation. Journal of Dairy Science, 74(4), 13951400.

Yasuda, K., Hashikawa, S., Sakamoto, H., Tomita, Y., Shibata, S., \& Fukata, T. 2007 A new synbiotic consisting of Lactobacillus casei subsp. casei and dextran improves milk production in Holstein dairy cows. Journal of Veterinary Medical Science, 69(2), 205208.

Zhang, R. Y., Yoon, I., Zhu, W. Y., \& Mao, S. Y. 2013 Effect of Saccharomyces cerevisiae fermentation product on lactation performance and lipopolysaccharide concentration of dairy cows. Asian-Australasian Journal of Animal Sciences, 26(8), 1137.

\section{How to cite this article:}

Yaswanth Naidu, Y., K. Ananda Rao, Ch. Venkata Seshaiah, D. Srinivas Kumar and Sri Lekha, M. 2021. Effect of Feeding Multi-Strain Probiotic on Feed Intake and Milk Production Performance in Murrah Buffaloes. Int.J.Curr.Microbiol.App.Sci. 10(05): 409-417. doi: https://doi.org/10.20546/ijcmas.2021.1005.048 